\title{
THE QUALITY OF TUBERCULOSIS SERVICES IN PATIENTS' PERSPECTIVES: A LITERATURE REVIEW
}

\author{
Kualitas Pelayanan Tuberkulosis dalam Perspektif Pasien: Tinjauan Pustaka \\ *Aufiena Nur Ayu Merzistya ${ }^{1,4}$, Mateus Sakundarno Adi ${ }^{1,2}$, Dwi Sutiningsih ${ }^{1,3}$, Sri Ratna Rahayu ${ }^{4}$ \\ ${ }^{1}$ School of Postgraduate Studies, Diponegoro University, Semarang, Indonesia \\ ${ }^{2}$ Public Health Faculty, Diponegoro University, Semarang, Indonesia \\ ${ }^{3}$ Epidemiology and Tropical Disease, Public Health Faculty, Diponegoro University, Semarang, Indonesia \\ ${ }^{4}$ Department of Public Health, Sport Science Faculty, Universitas Negeri Semarang, Indonesia \\ ${ }^{*}$ Correspondence: finamerzistya@gmail.com
}

\begin{abstract}
Background: The assessment from the patient's perspective is the assurance of TB service' quality to achieve the "End TB" target. The information regarding TB services' quality assessment in the dimensions of QUOTE TB Light is not widely found.

Aims: The study aims to review TB services' quality from the patients' perspective in the 7 dimensions of QUOTE TB Light.

Methods: This literature review study searched from 3 databases, namely PubMed, Science-Direct, and Google Scholar since July - October 2020. The inclusion criteria were research on TB services quality, patients' perspective, and patient assessment of 7 dimenssion. Articles assessed the other health services' quality and published before January 2015 was excluded.

Results: A total of 7 from 89 articles found were selected for review. The patients' assessments are based on their experiences or satisfactions. Most of the studies are satisfied with service availability, communication, patient-provider interactions, competence, and affordability. The patients' dissatisfactions about infrastructure and stigma acquired during treatment.

Conclusion: Infrastructure and stigma are assessed negatively. The continously evaluation and training for health workers need to be improved so they can serve patients well. The patients' perspectives can be the major consideration for providers to enhance the TB services' quality.
\end{abstract}

Keywords: Quality of TB services, QUOTE TB Light, patients' perspectives, Tuberculosis

\section{ABSTRAK}

Latar Belakang: Penilaian dari perspektif pasien adalah jaminan kualitas pelayanan untuk mencapai target "End TB". Informasi dan penelitian mengenai penilaian kualitas pelayanan TB dengan QUOTE TB Light tidak banyak ditemukan.

Tujuan: Tujuan penelitian ini untuk mengulas tentang kualitas pelayanan TB dari perspektif pasien dalam 7 dimensi QUOTE TB Light.

Metode: Penelitian literature review ini mencari artikel-artikel dari 3 database, yakni PubMed, ScienceDirect, and Google Scholar sejak bulan Juli - Oktober 2020. Kriteria artikel meliputi penelitian kualitas pelayanan TB, kepuasan/pengalaman pasien tentang pelayanan TB, penilaian pasien terhadap 7 dimensi QUOTE TB Light. Penelitian yang menilai kualitas pelayanan kesehatan lainnya dan terpublikasi sebelum Januari 2015 dieks/usi.

Hasil: Sebanyak 7 artikel dari 89 artikel yang ditemukan terpilih sesuai kriteria. Penilaian pasien berdasarkan pada pengalaman dan kepuasan mereka selama pengobatan. Sebagian besar penelitian puas dengan ketersediaan pelayanan, komunikasi informasi, interaksi pasien-petugas, kompetensi, seta keterjangkauan pelayanan. Ketidakpuasan pasien terjadi pada infrastruktur dan stigma yang diterima selama pengobatan.

Kesimpulan: Infrastruktur dan stigma adalah dimensi yang dinilai negatif. Evaluasi rutin dan pelatihan terhadap petugas kesehatan perlu ditingkatkan agar petugas mampu melayani pasien dengan baik. Perspektif pasien dapat menjadi pertimbangan utama penyedia untuk meningkatkan kualitas pelayanan dalam pengendalian TB.

Kata kunci: QUOTE TB Light, Kualitas Pelayanan TB, Perspektif pasien, Tuberkulosis 


\section{INTRODUCTION}

Tuberculosis (TB) is still a public health problem that is the leading cause of illness and the top 10 causes of death globally (WHO, 2020). According to World Health Organization (2020), there are 10 million people infected TB and 1.2 million deaths in the world in 2019. Based on the Global Tuberculosis Report 2020, in 20152019 there has been a decrease in new TB cases by $9 \%$ (142 to 130 cases per 100,000 population), but this decrease in TB cases is not on track with the 2020 target, namely a $20 \%$ reduction in cases globally. India (26\%), Indonesia (8.5\%), and China (8.4\%) are the three countries with the highest TB cases in the world (WHO, 2020).

The high number of TB cases globally is a driving force for TB control efforts. Since 2014, WHO has initiated a new strategy that accompanies the SDGs, namely the "End TB Strategy". This strategy focuses on achieving coverage of TB services and treatment in all regions of a country (WHO, 2015). Many countries have increased this coverage, but the quality of service has received little attention. This condition causes many TB cases in the world (Cazabon et al., 2017). To achieve the focus of "End TB Strategy", it is necessary to increase access to TB services and ensure that patients receive a sufficiently high level of TB care (Scott and Jha, 2014; Kruk, Larson and TwumDanso, 2016; Cazabon et al., 2017).

Patients are users of a health service, where patient-centered services can ensure that a health service is considered to be of good quality (Syachroni, 2018). Involving patients by considering their perspectives or views on the quality of TB services will be able to determine the patient's needs in treatment so that minimizing the occurrence of dropouts in treatment (Dirjen P2\&PL Kementerian Kesehatan RI, 2011).
Moreover, TB treatment which is included in the category of long-term treatment (at least 6 months) is prone to dropout from treatment. Patients who are satisfied with the services they received will be able to carry out regular treatment, maintain contact with health workers, comply with medical advice, and regularly use medical services (Rahmadiana, 2012; Menawati and Kurniawan, 2015; Bhatnagar, 2019)

The assessment of TB services' quality from the patient's perspective can be known from patients' satisfaction and experiences during treatment (Bhatnagar, 2019). There was a TB services wuality assessment tool developed by USAID is called QUOTE TB Light (Quality of Care as seen through the Eyes of the Patient). This tool assessed TB service quality from 9 dimensions: information communication, professional competence, availability of TB services, affordability, patient-provider interaction and counseling, infrastructure, relationship with TB-HIV, support, and stigma (Massaut, Broek and Kwaak, 2009). Many countries with a high TB burden, namely Cambodia, Indonesia, Mozambique, Nigeria, and Zambia have conducted assessments with this tool (USAID and TB Care I, 2015). The trials in Indonesia proved a need for improvement in quality of interaction between patientsproviders and professional competence (Kemenkes RI, 2014).

Other studies in Indonesia assessed that 2 dimenssions, relationship between TB-HIV and support (food, transportation and money) were deemed necessary for improvement (Farsida, Mahendradhata and Probandari, 2012). Two of the nine dimensions of QUOTE TB Light have been assessed in previous trials in Indonesia and those proved a need for improvement. The other seven dimensions need to be reviewed to provide references in quality improvement. Besides, to the best of our knowledge, no literature reviews that 
discuss the TB service quality assessments in the QUOTE TB Light dimenssions. So, the aim of this study is to review the TB services quality as assessed from the patient's perspective in the 7 dimessions of QUOTE TB Light.

\section{ANALYSIS AND DISCUSSION}

This literature review research started from searching of scientific articles or research results on 3 databases, namely PubMed, ScienceDirect, and Google Scholar from July - October 2020. The terms or keywords in this search used Indonesian or English, including Tuberculosis (Tuberkulosis), quality of TB care or treatment (kualitas pelayanan TB), QUOTE TB Light, patient perspectives, experiences, or satisfaction with TB services (perspektif, pengalaman, dan kepuasan pasien terhadap pelayanan TB). Inclusion criteria used to select articles include: (1) research on the quality of TB services (2) satisfaction or experience in the patient's perspective of TB services, (3) patient assessment of one or more than 7 dimensions of TB service quality in QUOTE TB Light. While exclusion criteria were (1) duplicated article, (2) assessment of service quality in TB co-infection (such as TB-HIV, TB-DM, etc) or others, and (3) providers' or health workers' perspective, and (4) the articles published before January 2000 - 2015. We tried to review the latest studies to find out the current development of TB service quality, especially since 2015 WHO has focused more on TB services in TB control efforts that were initiated in the "End TB Strategy". Therefore, the articles that we screened were articles published in the last 5 years or before January 2015 .

A total of 89 articles were identified by searching with these keywords in 3 databases. Furthermore, we removed 6 duplicated articles. There were 83 articles that are potential to be screened, starting from the abstract to the full-text articles. From the 83 potential articles, seventy-six (76) were excluded because they did not meet the inclusion criteria. Fifty-eight (58) articles were found discussing about assessment of TB service quality, so 25 articles were excluded from this review. Thirty-one (31) articles were fulfilling inclusion criterion 1, 2, and 3. However, twenty-four (24) of thirty-one (31) articles published before January 2000 - 2015.

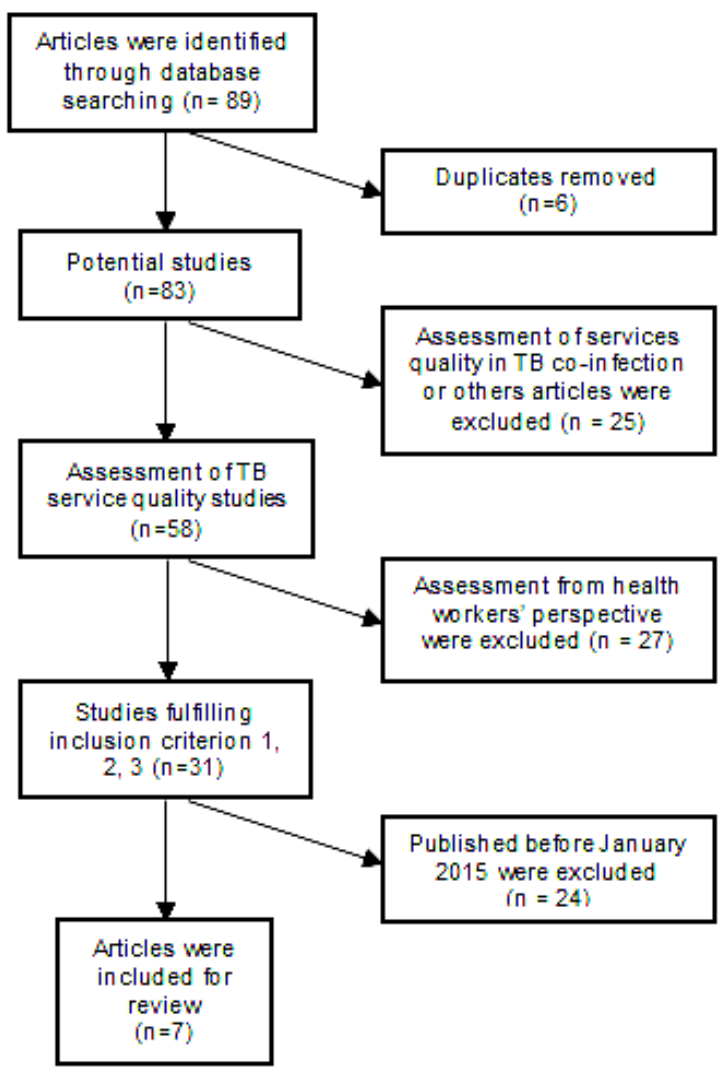

Figure 1. PRISMA diagram

As a result, the total number of articles that were included for review were 7 full-text articles. The flow chart for selecting articles is presented in Figure 1.

\section{Characteristics of the selected articles}

A total of 89 articles found in 3 journals search databases, seven (7) articles were selected to review. The table 
1 presents the characteristics of the 7 selected articles.

Three of seven articles (42.8\%) used analytic cross-sectional, others used descriptive cross-sectional $(3 ; 42.8 \%)$ and mixed-method designs $(1 ; 15.4 \%)$. The several studies conducted quality assessments at primary health facilities, health centers, and even hospitals. However, two studies did not mention the type of health facilities $(2 ; 28.6 \%)$. The study areas or countries were generally located in developing countries with the world's highest TB burden. The countries

Tabel 1. Characteristics of the selected articles

\begin{tabular}{|c|c|c|c|c|c|}
\hline Studies & $\begin{array}{l}\text { Study } \\
\text { Design }\end{array}$ & $\begin{array}{l}\text { Types of } \\
\text { Health } \\
\text { Facilities }\end{array}$ & $\begin{array}{c}\text { City/District, } \\
\text { Country }\end{array}$ & Samples & $\begin{array}{c}\text { Patient } \\
\text { Categories }\end{array}$ \\
\hline $\begin{array}{l}\text { Mukasa, Glass, } \\
\text { and } \\
\text { Mnatzaganian, } \\
2015 \text {, Ethnicity } \\
\text { and patient } \\
\text { satisfaction with } \\
\text { tuberculosis care: } \\
\text { A cross-sectional } \\
\text { study }\end{array}$ & $\begin{array}{l}\text { Descriptive } \\
\text { Cross- } \\
\text { sectional }\end{array}$ & Hospital & $\begin{array}{l}\text { Melbourne, } \\
\text { Australia and } \\
\text { Malawi, sub- } \\
\text { Saharan } \\
\text { Africa }\end{array}$ & 194 & $\begin{array}{l}\text { Pulmonary } \\
\text { TB } \\
\text { treatment } \\
\text { period }\end{array}$ \\
\hline $\begin{array}{l}\text { Onyeonoro et al., } \\
2015, \text { Evaluation } \\
\text { of Patient } \\
\text { Satisfaction with } \\
\text { Tuberculosis } \\
\text { Services in } \\
\text { Southern Nigeria }\end{array}$ & $\begin{array}{l}\text { Cross- } \\
\text { sectional }\end{array}$ & $\begin{array}{l}\text { Tertiary, } \\
\text { secondary } \\
\text { health } \\
\text { facilities, } \\
\text { and PHCs }\end{array}$ & $\begin{array}{l}\text { Six states of } \\
\text { Southern } \\
\text { Nigeria }\end{array}$ & 378 & $\begin{array}{l}\text { Pulmonary } \\
\text { TB } \\
\text { treatment } \\
\text { period }\end{array}$ \\
\hline $\begin{array}{l}\text { Ssengooba et al., } \\
2016, \text { Patient } \\
\text { satisfaction with } \\
\text { TB care clinical } \\
\text { consultations in } \\
\text { Kampala: A cross } \\
\text { sectional study }\end{array}$ & $\begin{array}{l}\text { Descriptive } \\
\text { Cross- } \\
\text { sectional }\end{array}$ & PHCs & $\begin{array}{l}\text { Kampala, } \\
\text { Uganda }\end{array}$ & 178 & $\begin{array}{l}\text { Pulmonary } \\
\text { TB } \\
\text { treatment } \\
\text { period }\end{array}$ \\
\hline $\begin{array}{l}\text { Kurniawan, } \\
\text { Andrajati and } \\
\text { Supardi, 2017, } \\
\text { Perbandingan } \\
\text { Kualitas } \\
\text { Pelayanan } \\
\text { Puskesmas } \\
\text { Kecamatan Koja } \\
\text { dan Tarumajaya } \\
\text { terhadap } \\
\text { Kepatuhan Minum } \\
\text { Obat Pasien } \\
\text { Tuberkulosis } \\
\end{array}$ & $\begin{array}{l}\text { Descriptive } \\
\text { Cross- } \\
\text { sectional }\end{array}$ & PHCs & $\begin{array}{l}\text { North Jakarta } \\
\text { and Bekasi, } \\
\text { Indonesia }\end{array}$ & 322 & $\begin{array}{l}\text { Pulmonary } \\
\text { TB } \\
\text { treatment } \\
\text { period }\end{array}$ \\
\hline $\begin{array}{l}\text { Bucyibaruta et al., } \\
2018, \text { Patients' } \\
\text { perspectives of } \\
\text { acceptability of } \\
\text { ART, TB and }\end{array}$ & $\begin{array}{l}\text { Mixed } \\
\text { methods }\end{array}$ & $\begin{array}{l}\text { TB health } \\
\text { services* }\end{array}$ & $\begin{array}{l}\text { Johannesburg } \\
\text {, South Africa }\end{array}$ & 297 & $\begin{array}{l}\text { Pulmonary } \\
\text { TB } \\
\text { treatment } \\
\text { period }\end{array}$ \\
\hline
\end{tabular}


maternal health

services in a

subdistrict of

Johannesburg,

South Africa

\begin{tabular}{|c|c|c|c|c|c|}
\hline $\begin{array}{l}\text { Davtyan et al., } \\
\text { 2019, Quality of } \\
\text { care provided to } \\
\text { tuberculosis } \\
\text { patients in } \\
\text { Armenia: How } \\
\text { satisfied are the } \\
\text { patients? }\end{array}$ & $\begin{array}{l}\text { Cross- } \\
\text { sectional }\end{array}$ & $\begin{array}{l}\text { Primary } \\
\text { health } \\
\text { facilities }\end{array}$ & Armenia & 505 & $\begin{array}{l}\text { Pulmonary } \\
\text { TB } \\
\text { treatment } \\
\text { period }\end{array}$ \\
\hline $\begin{array}{l}\text { Peresu et al., } \\
2020, \text { Patient } \\
\text { satisfaction with } \\
\text { directly observed } \\
\text { treatment and } \\
\text { multidrug-resistant } \\
\text { tuberculosis } \\
\text { injection } \\
\text { administration by } \\
\text { lay health workers } \\
\text { in rural Eswatini }\end{array}$ & $\begin{array}{l}\text { Cross- } \\
\text { sectional }\end{array}$ & $\begin{array}{l}\text { MDR-TB } \\
\text { health } \\
\text { facilities* }\end{array}$ & $\begin{array}{l}\text { Shiselweni, } \\
\text { Eswatini }\end{array}$ & 78 & $\begin{array}{l}\text { MDR-TB } \\
\text { treatment } \\
\text { period }\end{array}$ \\
\hline
\end{tabular}

PHC = Public Health Centers

in Africa's continent were mostly found in this study $(5 ; 71.4 \%)$, others in Indonesia, Armenia, and Australia. Most (6; 85.7\%) articles chose Pulmonary TB patients during the treatment period as samples. Only one used MDR-TB patient category.

\section{Tuberculosis service quality based on QUOTE TB Light}

The review of the 7 research articles in Table 2, identified findings regarding assessing TB care quality from patients' perspective. This discussion, patients' assessment of TB services' quality is influenced by satisfaction and experience during treatment at a health facility. The patient's satisfaction was found in the 7 dimensions of QUOTE TB Light, shown at table 2. The existence of an assessment of the aspects in these dimensions can be used as determinant in improving the quality of TB services (Bhatnagar, 2019).

\section{Availability of TB Services}

Two of the seven studies provided a good assessment of service access in the dimension of TB service availability (Onyeonoro et al., 2015; Kurniawan, Andrajati and Supardi, 2017). The patients felt no problem with access to TB services at the health facilities. The patients in Southern Nigeria's public health services were satisfied with access to affordable TB services. This satisfaction was associated with the increase in DOTS closer to the community in recent years (Onyeonoro et al., 2015). Similiarly, research conducted in Indonesia which proves that the reach of the PHC's distance from the patient's residence affects the patient's adherence to treatment. The affordability of the PHC by patients will make it easier for them to carry out treatment. Patients do not feel lazy to routinely carry out treatment because they do not feel the need to pay for accommodation, time is wasted a lot on travel, and energy (Kurniawan, Andrajati and Supardi, 2017). 
Table 2. The main findings on patient experience of TB service quality

Dimension

Availability of TB services

\section{Key findings}

- Access to services is considered good by patients.

- Access to health facilities is affordable for patients in SN (Onyeonoro et al., 2015).

- The location of PHC that is easily accessible has a big influence on the level of patient medication adherence (Kurniawan, Andrajati and Supardi, 2017).

- Patients are uncomfortable with long waiting times when making doctor appointments and queuing for services (Ssengooba et al., 2016).

Communication - Health education in private health facilities received by patients is and Information considered unsatisfactory (Onyeonoro et al., 2015).

- Health workers' explanation about what has been done to patients is considered very good (Ssengooba et al., 2016).

Patient-Provider - Ethnic Australians in developing countries tend to be dissatisfied with Interaction and the unsatisfactory time of counseling with nurses (Mukasa, Glass and Counseling Mnatzaganian, 2015)

- Patients are satisfied with the counseling service because of the certainty and clearer understanding of the disease they are suffering from. The relationship between patients and staff is more intense and increased (Onyeonoro et al., 2015).

- Sufficient time for discussion is a major factor in high patient satisfaction (Ssengooba et al., 2016).

- The patient accepts the counseling carried out with satisfaction because of the staff's good empathy towards the patient (Davtyan et al., 2019).

Affordability - Even though MDR-TB treatment costs are free, patients face other charges (food, transport, loss of job), affecting patient satisfaction with services. (Peresu et al., 2020).

Infrastructure - Patients are not comfortable with service facilities, namely insufficient
and adequate seating at Tarumajaya PHC, Indonesia (Kurniawan, Andrajati and Supardi, 2017).

- There are infrastructure constraints that force counselors to provide confidential information such as HIV status to other patients (Bucyibaruta et al., 2018).

\begin{tabular}{|c|c|}
\hline $\begin{array}{l}\text { Professional } \\
\text { competence }\end{array}$ & $\begin{array}{l}\text { - Expertise (accuracy, thoroughness, carefulness, competence) of health } \\
\text { workers is an important factor in high patient satisfaction (Ssengooba et } \\
\text { al., 2016). }\end{array}$ \\
\hline $\begin{array}{l}\text { Stigma in TB } \\
\text { services }\end{array}$ & $\begin{array}{l}\text { - Most of the patients experienced bad treatment by the attitudes and } \\
\text { behavior of health workers(Onyeonoro et al., 2015) } \\
\text { Most of the patients experienced bad treatment by the attitudes } \\
\text { and behavior of health workers (Onyeonoro et al., 2015) } \\
\circ \text { Some officers ask for money for TB services that should be free } \\
\text { (Onyeonoro et al., 2015) } \\
\text { The attitude of politeness, respect, sensitivity, and friendliness of } \\
\text { officers is considered good by the patient (Mukasa, Glass and } \\
\text { Mnatzaganian, 2015; Ssengooba et al., 2016). } \\
\text { Nurses are rude and have negative behavior, which is indicated to } \\
\text { be one reason for some patients to drop out of treatment } \\
\text { (Bucyibaruta et al., 2018). }\end{array}$ \\
\hline
\end{tabular}


This finding is supported by research conducted in Nepal, India, with the world's highest burden. Research on barriers to access the health services in Nepal, India found that there are causes of barriers to health services due to long distances, poor road conditions, and costs for long trips that must be taken, which encourages people to visit more traditional healers than health services. These barriers to health care in Nepal, India affected adherence and patient delay in treatment (Marahatta et al., 2020). The delay in treatment impacted the disease's severity and spread, which is increasingly widespread to family members and communities (Saifodine et al., 2013; Makwakwa et al., 2014).

In the QUOTE TB Light assessment, availability of TB services include the affordability of service access distances and consists of the waiting time for TB services (Massaut, Broek and Kwaak, 2009). As reported in the selected article, the long waiting time when making a doctor's appointment caused patients to be uncomfortable with services' availability (Ssengooba et al., 2016). Not only when making appointments, but patients also experienced long waiting times while in TB services when queuing for treatment (Ssengooba et al., 2016). This finding contrasts with the conclusions of another study in India, where patients were satisfied with the waiting time to get medical services with a short waiting duration at health facilities in Masya Pradesh and Kamataka City (Rashmi and Vijaykumar, 2010; Rai et al., 2017). The availability of services is one indicator of the minimum service standards for a health facility. One of the factors affecting patient compliance in taking medication is the availability of services.(Dwi Laksono et al., 2012).

\section{Communication and Information}

Other dimensions found to be important in assessing service quality included communication and information. In QUOTE TB Light, the assessed aspects are communication and information, namely information that is explained accurately and correctly to patients regarding the disease, treatment, examinations, and prevention of TB transmission to patients. Onyeonoro et.al (2015) study in Six states of Southern Nigeria found that the dissatisfaction received by patients regarding TB health education in private health facilities (Onyeonoro et al., 2015). In contrast, another selected article found that patients rated the staff's information very well. Patients said the officers explained well what had been done to patients during the TB treatment period (Ssengooba et al., 2016).

Health communication carried out by officers properly will also create a good impression for patients, and vice versa The delivery of accurate, correct, and clear information will influence the patient to comply with the treatment as expected by the officer (Notoatmodjo, 2005; Rahmadiana, 2012; Bhatnagar, 2019). Besides, communication will also increase the patient's knowledge of the disease and the medication carried out so that the patient's quality of life will often improve with patient compliance and awareness in treatment due to the correct information from the staff (Notoatmodjo, 2005).

\section{Patient-Provider Interaction and Counseling}

Good patient-provider interactions must also accompany the existence of good communication and information. Table 2 shows that most of the research results convey patient satisfaction with the interaction and counseling received. Sufficient discussion time is a major factor of high patient satisfaction with the TB 
services they receive (Mukasa, Glass and Mnatzaganian, 2015; Ssengooba et al., 2016). Counseling carried out with officers is well established because the officers' empathy is well-received (Davtyan et al., 2019). As with the communication dimension, the effectiveness of patientofficer interactions will impact patient treatment outcomes by the staff's suggestions and expectations and increase medication adherence (Menawati and Kurniawan, 2015). It is because sometimes patients also want to take part in their treatment decisions, to be able to talk, discuss problems they are experiencing, and want to be heard.

Patient and provider interactions can also occur because of counseling. Counseling is a process of assisting clients, in this case, TB patients, to resolve their problems (Gunarsa, 2007). Counseling in TB treatment is important to control and monitor TB patients during the following treatment. The previous findings indicate a significant relationship between counseling and compliance with TB patients while taking drugs (Hussain, A. Malik and Hussain, 2016; Aldina, Hermanto and Manggasa, 2020). There were $62.5 \%$ of TB patients who were not adherent in taking drugs without good counseling (Aldina, Hermanto and Manggasa, 2020). Providing information about TB and its treatment is equally important in counseling. Tuberculosis treatment that takes a long time and requires extra adherence causes the need for information on TB treatment, prevention, health implications, and the family's role in recovery in patients is very high (Pasek, Suryani and Murdani, 2013).

\section{Affordability}

The dimension of affordability is also the main thing for patients in assessing the quality of TB services. Although all TB patients can currently afford the cost of access to services due to free TB treatment, patients do not necessarily feel that the fees do not burden them. During treatment, patients also consider other costs that they must pay, such as transportation costs, meals, cost of work left to take medicines at health facilities, and the reduced income due to some of them having to stop working due to TB. This condition will cause patient to fell dissatisfied with TB services quality (Peresu et al., 2020). If the patient feels burdened by these costs, it will contribute to the failure of TB treatment (Long et al., 2011), which will lead to an increase in household transmission to death (Xu et al., 2010).

Catastrophic costs of TB are all total costs that must be incurred by patients and their families, including direct and indirect costs (WHO, 2017). Direct cost of treatment includes administrative, consultation, laboratory, drug, and hidden costs. Indirect costs include transportation costs, loss of work and income, and basic needs (Sari et al., 2017). Tuberculosis patients generally feel burdened by indirect costs because the government do not cover them. Research in Indonesia reported the incidence of disaster costs in households in 282 TB patients was $38 \%$. and patients needed financial support primarily to cover indirect costs, such as loss of jobs, transportation, and food supplements (Fuady et al., 2019). It can prove that even though programs in TB control provide free treatment to patients, patients are burdened by costs outside of TB treatment.

\section{Professional Competence}

The professional competencies are the skills, expertise, and abilities of health workers in performing service standards, including patient examination, treatment assistance, and all matters relating to providing services to patients (Bustami, 2011). It is proven in a study in Kampala, Uganda, that professional competence is 
an important factor in high patient satisfaction. Patients feel satisfied with the expertise that includes thoroughness, carefulness, and competence of health workers they saw and accepted during treatment in health center, Kampala, Uganda (Ssengooba et al., 2016). The research conducted in Ethiopia revealed that officers' professional service provision was a predictor factor for patient satisfaction in carrying out treatment. This study proven that satisfaction with the services received will affect compliance with the staff's suggestions until the treatment's success (Nezenega, Gacho and Tafere, 2013).

The professional competence also includes competent care, which is the provision of care and management for all TB patients must comply with the most recent evidence-based guidelines that have been determined, including diagnostic accuracy (Arsenault, RoderDeWan and Kruk, 2019). Many health care providers in high burden countries for TB do not comply with International Standard TB care guidelines. It has been reported in several studies with the standard patient method (Das et al., 2015; Daniels et al., 2017).

\section{Infrastructure}

The negative experiences received by patients in the study occurred in two main dimensions, including TB service infrastructure. Patients are dissatisfied with the infrastructure they had gotten during treatment. One of Indonesia's research was that the facilities at the Tarumajaya PHC, Indonesia, which was not adequate. The patients were uncomfortable with seats in these health facilities, where often they did not get a seat when queuing up, so they have to stand for some time (Kurniawan, Andrajati and Supardi, 2017). Likewise, another study in TB health service in a subdistrict Johannesburg, Souht Arica revealed that there were frequent infrastructure constraints and made patients uncomfortable during counseling. A patient even described infrastructure constraints forcing the counselor to give confidential information to other patients (Bucyibaruta et al., 2018).

The comfort, availability, and cleanliness of existing health services facilities can be predictor factors for patient satisfaction in carrying out treatment (Nezenega, Gacho and Tafere, 2013). In Ethiopia, there are intrinsic differences in the types of health facilities, such as inherent differences and infrastructure conditions between primary and tertiary hospitals affected the low level of patient satisfaction with the cleanliness of waiting room facilities in health facilities (Mesfin and Gintamo, 2019). Besides, in efforts to control TB in Brazil, the infrastructure aspect was an important component that needs significant improvements to achieve maximum TB control (Bustami, 2011).

\section{Stigma in TB services}

The patient's dissatisfaction also occurred in the aspect of stigma. In QUOTE TB Light, the focus of stigma is the treatment of the staff and patients' health system during treatment. Most of the studies found patient dissatisfaction with health workers' attitudes and treatment towards them during treatment. Research in Southern Nigeria discovered that patients were dissatisfied with staff's attitude toward them. Patients regret the attitude of health workers who collect money during TB treatment which should be free. (Onyeonoro et al., 2015). A study by Bucyibaruta et. al. (2018) in the subdistrict of Johannesburg, South Arica also reported that there was stigma and mistreatment of health workers towards their patients. Some patients admit that the nurse was rude to them. This behavior led some patients to decided to stop TB treatment. 
Infectious diseases which are common especially in the middle-income countries are often considered a bad disease. Tuberculosis is one of infectious disease that has received much negative stigma in society. The negative stigma in TB patients is due to the fear of easily transmitted TB, loss of social status in the community, fear of social isolation, exclusion, gossip, failure of the marriage, neglect of families, and fear of sexual or verbal abuse (Mukerji and Turan, 2018; Thomas and Stephen, 2020). TB patients with HIV infection are more at risk of receiving negative stigma in society. It is possible because HIV has a high stigma, where people diagnosed with HIV are more often viewed negatively in society (Duko et al., 2019).

Health workers are among those who play a role in TB control (Lestyoningrum et al., 2020), especially the stigma that occurs in TB patients. Their role is expected to be able to encourage the patients to remain adherent to treatment during the negative stigma that patients receive. Hence, even health workers who are a milestone in TB control carry out this stigma. There is much negative stigma about TB patients being received from health care facilities. Unfavorable treatment, rude attitudes, rejection and differences in the standard of care provided are sometimes carried out by providers, health workers, and other patients (Mukasa, Glass and Mnatzaganian, 2015; Ssengooba et al., 2016).

Stigma of TB is an important social determinant of health (Craig et al., 2017). The occurrence of stigma will certainly affect the diagnosis, treatment, and treatment success of the patient. Patients will be reluctant to take medication and delay getting treatment (Cremers et al., 2015) to cause distrust patients in health facilities. In TB control efforts, stigma must be eliminated, especially in health facilities, because it will impact increasing patient adherence to treat (Nyblade et al., 2019).

\section{Implications for Service Providers in Improving the Quality of TB Services}

This review highlights the assessment of TB patients' perspectives on TB service quality based on the seven QUOTE TB Light dimensions. The findings of this review indicate that patients provided mixed ratings of TB services during treatment. The patients' assessment is based on the patient's experience and satisfaction in getting service during treatment. Besides, the evaluation of the quality of service received by patients greatly affects the patient's subsequent actions in therapy, one of which is to stop TB treatment prematurely. Thus, service providers need to consider the patient's assessment of the TB's treatment service quality to develop and improve the quality of TB health services.

We would like to highlight several key points in the results of this review that might be considered. First, the patient's decision to drop out of treatment is influenced by the patient's experience while receiving TB services in health facilities. It proves that service quality is one of the main keys to patient compliance in TB treatment, in which TB disease is an infectious disease with a long treatment time and treatment adherence is required to achieve a cure. Providers need to pay attention and consider TB patients' needs and desires in TB care. It is important to have a personal and strategic approach to the patient and the patient's family so that they feel included and listened to during treatment. Besides, the provider can do limited interviews routinely to involve patients in TB service quality improvement, using a quality assessment tool, namely QUOTE TB Light, with easy 
use by service providers and health practitioners.

Second, our review found that most of the articles discussed the negative stigma that patients received in the health facilities they visited. Different treatment with other patients, rude attitude, disrespect, and withdrawal of money outside of medical expenses are reported in several articles we reviewed. This condition will again impact patient adherence to treatment (Onyeonoro et al., 2015; Ssengooba et al., 2016; Bucyibaruta et al., 2018). The stigma of TB does not only occur in the community, even health workers, which are a milestone in TB control, actually carry out this stigma. It should be a concern for service providers. Improving the quality of human resources needs to be done. Stopping stigma in health facilities can be done by evaluating performance and increasing training for health workers in health practices and morally, attitudes, and behavior.

Third, the assessment of service quality is measured based on patient perceptions is accepted as an important indicator in measuring the quality of service (Woodring et al., 2004). Various countries use patient satisfaction survey results as the main criterion in quality assurance and management of the health system. However, there is no universally accepted way of measuring patient satisfaction with health services. Satisfaction is a multi-dimensional concept that allows for differences in measurement. In this review, various methods are used to report patient perceptions of service quality so that there is no consistent measurement tool in measuring patient satisfaction (Mesfin and Gintamo, 2019).

\section{CONCLUSION}

The assessment and negative experience which are received by patients about TB services are often the reason patients stop treatment. For health service providers and policy makers, quality improvement needs to be more focused on 1) involving patients in assessing the quality of services, 2) evaluating the quality of services that is carried out regularly and systematically, and 3 ) it is important to carry out regular training for health workers so that they can treat and take good care of patients and improve their competence.

Focusing on patient-centered services could support in identifying the real needs of the patient so that it is hoped that adherence to TB treatment will increase. Further research is needed in the application of QUOTE TB Light in TB service facilities to determine the current condition of TB services in Indonesia.

\section{CONFLICT OF INTEREST}

The author states that there is no conflict of interest in this study.

\section{REFERENCES}

Aldina, N. N., Hermanto, R. B. B. and Manggasa, D. D. (2020) 'Hubungan Konseling dengan Kepatuhan Minum Obat Anti Tuberkulosis Pasien Tuberkulosis di Kabupaten Poso', Madago Nursing Journal, 1(1), pp. 1-6. doi: 10.33860/mnj.v1i1.294.

Arsenault, C., Roder-DeWan, S. and Kruk, M. E. (2019) 'Measuring and improving the quality of tuberculosis care: A framework and implications from the Lancet Global Health Commission', Journal of Clinical Tuberculosis and Other Mycobacterial Diseases. Elsevier, 16, p. 100112. doi: 10.1016/j.jctube.2019.100112.

Bhatnagar, H. (2019) 'User-experience and patient satisfaction with quality of tuberculosis care in India: A mixed-methods literature review', 
Journal of Clinical Tuberculosis and Other Mycobacterial Diseases. Elsevier, 17, p. 100127. doi: 10.1016/j.jctube.2019.100127.

Bucyibaruta, B. J. et al. (2018) 'Patients' perspectives of acceptability of ART, TB and maternal health services in a subdistrict of Johannesburg, South Africa', BMC Health Services Research. BMC Health Services Research, 18(1), pp. 1-15. doi: 10.1186/s12913018-3625-5.

Bustami (2011) Penjaminan Mutu
Pelayanan Kesehatan dan
Akseptabilitasnya.
Erlangga.

Cazabon, D. et al. (2017) 'Quality of tuberculosis care in high burden countries: the urgent need to address gaps in the care cascade', International Journal of Infectious Diseases. The Author(s), 56(2017), pp. 111-116. doi: 10.1016/j.ijid.2016.10.016.

Craig, G. M. et al. (2017) 'Tuberculosis stigma as a social determinant of health: a systematic mapping review of research in low incidence countries', International Journal of Infectious Diseases. International Society for Infectious Diseases, 56, pp. 90-100. doi: 10.1016/j.ijid.2016.10.011.

Cremers, A. L. et al. (2015) 'Assessing the consequences of stigma for tuberculosis patients in urban Zambia', PLoS ONE, 10(3), pp. 116. doi: 10.1371/journal.pone.0119861.

Daniels, B. et al. (2017) 'Use of standardised patients to assess quality of healthcare in Nairobi, Kenya: A pilot, cross-sectional study with international comparisons', BMJ Global Health, 2(e000333). doi: 10.1136/bmjgh2017-000333.

Das, J. et al. (2015) 'Use of standardized patients to assess quality of tuberculosis care: a pilot, cross- sectional study', Lancet Infectious Disease, 15(11), pp. 1305-1313. doi: $10.1016 / S 1473-$ 3099(15)00077-8.

Davtyan, K. et al. (2019) 'Quality of care provided to tuberculosis patients in Armenia: How satisfied are the patients?', Journal of Infection in Developing Countries, 13(5), pp. 28-34. doi: 10.3855/jidc.10873.

Dirjen P2\&PL Kementerian Kesehatan RI (2011) Terobosan Menuju Akses Universal, Strategi Nasional Pengendalian TB di Indonesia 2010-2014, Stop TB. Jakarta: Ministry of Health. Available at: http://www.searo.who.int/indonesia/ topics/tb/stranas_tb-20102014.pdf?ua=1.

Duko, B. et al. (2019) 'Perceived Stigma and Associated Factors among Patient with Tuberculosis, Wolaita Sodo, Ethiopia: Cross-Sectional Study', Tuberculosis Research and Treatment, 2019, pp. 1-5. doi: $10.1155 / 2019 / 5917537$.

Dwi Laksono, A. et al. (2012) 'Kajian Standar Pelayanan Minimal Penyakit Tuberkulosis Terkait Indikator Millenium Development Goals (Review The Tuberculosis Minimum Health Service Standard Associated To Indicators Of Millinium Development Goals)', Buletin Penelitian Sistem Kesehatan, 15(April 2017), pp. 259-270.

Farsida, Mahendradhata, Y. and Probandari, A. (2012) 'Kualiatas Layanan Tuberkulosis Menurut Sudut Pandang Pasien di Rumah Sakit Pemerintah dan Swasta di Jakarta Utara', Jurnal Manajemen Pelayanan Kesehatan, 15(4), pp. 161-165.

Fuady, A. et al. (2019) 'Effect of financial support on reducing the incidence of catastrophic costs among tuberculosis-affected households in Indonesia: Eight simulated scenarios', Infectious Diseases of Poverty. Infectious Diseases of 
Poverty, 8(10), pp. 1-14. doi: 10.1186/s40249-019-0519-7.

Gunarsa, S. (2007) Konseling dan Psikoterapi. Jakarta: PT BPK Gunung Mulia.

Hussain, S., A. Malik, A. and Hussain, Z. (2016) 'A Randomized Controlled Intervention Trial: Effect of Counselling on Treatment Adherence and Self-Esteem of Women Patients Receiving Tuberculosis Treatment', Open Medicine Journal, 3(1), pp. 27-33. doi:

\section{$10.2174 / 1874220301603010027$.}

Kemenkes RI (2014) 'Warta Tuberkulosis Indonesia: Wadah Informasi Gerakan Terpadu Nasional TB', Warta Tuberkulosis Indonesia, pp. 1-8.

Kruk, M. E., Larson, E. and Twum-Danso, N. A. Y. (2016) 'Time for a quality revolution in global health', The Lancet Global Health, 4(9), pp. e594-e596. doi: 10.1016/S2214109X(16)30131-0.

Kurniawan, A. H., Andrajati, R. and Supardi, S. (2017) 'Perbandingan Kualitas Pelayanan Puskesmas Kecamatan Koja dan Tarumajaya terhadap Kepatuhan Minum Obat Pasien Tuberkulosis', Buletin Penelitian Kesehatan, 45(3), pp. 187-196. doi: 10.22435/bpk.v45i3.6461.187-196.

Lestyoningrum, S. D. et al. (2020) 'the Effect of Organization'S Structure and Task Characteristics on Team Effectiveness in Tuberculosis Prevention Program', Jurnal Administrasi Kesehatan Indonesia, $8(2), \quad$ p. $151 . \quad$ doi: 10.20473/jaki.v8i2.2020.151-163.

Long, Q. et al. (2011) 'Patient medical costs for tuberculosis treatment and impact on adherence in China: A systematic review', BMC Public Health, 11(393), pp. 1-9. doi: 10.1186/1471-2458-11-393.

Makwakwa, L. et al. (2014) 'Patient and heath system delays in the diagnosis and treatment of new and retreatment pulmonary tuberculosis cases in Malawi', BMC Infectious Diseases, 14(132), pp. 1-9. doi: 10.1186/1471-2334-14132.

Marahatta, S. B. et al. (2020) 'Barriers in the access, diagnosis and treatment completion for tuberculosis patients in central and western Nepal: A qualitative study among patients, community members and health care workers', PLOS ONE, 15(1), pp. 1-18. doi: 10.1371 /journal.pone.0227293.

Massaut, S., Broek, J. van den and Kwaak, A. van der (2009) 'QUOTE TB Light', in TB Care Publicatons. The Hague: Project Management Unit TB CAP.

Menawati, T. and Kurniawan, H. (2015) 'Pentingnya Komunikasi Dalam Pelayanan Kesehatan Primer', Jurnal Kedokteran Syiah Kuala, 15(2), pp. 120-124.

Mesfin, D. and Gintamo, T. (2019) 'Patient satisfaction and associated factors with services provided at outpatient departments', International Journal of Public Health Science (IJPHS), $8(4), \quad$ p. $406 . \quad$ doi: 10.11591/ijphs.v8i4.20375.

Mukasa, J. P., Glass, N. and Mnatzaganian, G. (2015) 'Ethnicity and patient satisfaction with tuberculosis care: A cross-sectional study', Nursing and Health Sciences, 17(3), pp. 395-401. doi: 10.1111/nhs.12202.

Mukerji, R. and Turan, J. M. (2018) 'Exploring manifestations of tbrelated stigma experienced by women in Kolkata, India', Annals of Global Health, 84(4), pp. 727-735. doi: 10.29024/aogh.2383.

Nezenega, Z. S., Gacho, Y. H. and Tafere, T. E. (2013) 'Patient satisfaction on tuberculosis treatment service and adherence to treatment in public health facilities of Sidama zone, South Ethiopia', BMC Health 
Services Research, pp. 1-8.

Notoatmodjo, S. (2005) Promosi Kesehatan: Teori dan Aplikasi. Jakarta: Rineka Cipta.

Nyblade, L. et al. (2019) 'Stigma in health facilities: Why it matters and how we can change it', BMC Medicine. BMC Medicine, 17(1), pp. 1-15. doi: 10.1186/s12916-019-1256-2.

Onyeonoro, U. U. et al. (2015) 'Evaluation of Patient Satisfaction with Tuberculosis Services in Southern Nigeria', Health Services Insights, 8, pp. 25-33. doi: 10.4137/HSI.S27177.

Pasek, M. S., Suryani, N. and Murdani, P. (2013) 'Tuberkulosis Dengan Kepatuhan Pengobatan', Jurnal Magister Kedokteran Keluarga, 1(1), pp. 14-23. Available at: https://media.neliti.com/media/publi cations/13494-ID-hubunganpersepsi-dan-tingkat-pengetahuanpenderita-tuberkulosis-dengankepatuha.pdf.

Peresu, E. et al. (2020) 'Patient satisfaction with directly observed treatment and multidrug-resistant tuberculosis injection administration by lay health workers in rural Eswatini', African Journal of Primary Health Care and Family Medicine, 12(1), pp. 1-10. doi: 10.4102/PHCFM.V12I1.2257.

Rahmadiana, M. (2012) 'Komunikasi Kesehatan: Sebuah Tinjauan*', Jurnal Psikogenesis, 1(1), pp. 8894.

Rai, N. et al. (2017) 'A cross sectional study on evaluation of satisfaction level of TB patients enrolled for directly observed treatment, short course chemotherapy in a district of Central India', International Journal of Community Medicine and Public Health, 4(1), pp. 5-8. doi: $10.18203 / 2394-$ 6040.ijcmph20164419.

Rashmi and Vijaykumar, B. (2010) 'Client Satisfaction in Rural India for Primary Health Care - A Tool for
Quality Assessment', AL Ameen J Med Sci, 3(2), pp. 109-114.

Saifodine, A. et al. (2013) 'Patient and health system delay among patients with pulmonary tuberculosis in Beira city, Mozambique', BMC Public Health, 13(559), pp. 1-7. doi: 10.1186/1471-2458-13-559.

Sari, I. D. et al. (2017) 'Analisis Biaya Tuberkulosis Paru Kategori Satu Pasien Dewasa di Rumah Sakit di DKI Jakarta', Jurnal Kefarmasian Indonesia, 8(1), pp. 44-54.

Scott, K. W. and Jha, A. K. (2014) 'Putting Quality on the Global Health Agenda', New England Journal of Medicine, 371(1), pp. 1-3. doi: 10.1056/NEJMp1402969.

Ssengooba, W. et al. (2016) 'Patient satisfaction with TB care clinical consultations in Kampala: A cross sectional study.', African Health Sciences, 16(4), pp. 1101-1108. doi: 10.4314/ahs.v16i4.28.

Syachroni (2018) 'Perceived Quality of Care and Patient Satisfaction on Tuberculosis DOTS Services in Urban Primary Health Center', International Journal of Public Health and Clinical Sciences, 5(4), pp. 194-203.

Thomas, B. E. and Stephen, A. (2020) 'Tuberculosis related stigma in India: roadblocks and the way forward', Expert Review of Respiratory Medicine. Taylor \& Francis, 00(00), pp. 1-3. doi: 10.1080/17476348.2020.1826314.

USAID and TB Care I (2015) TB CARE I Patient Centered Approach. Den Haag. Available at: https://www.kncvtbaac.org/uploade d/2015/09/TB_CARE_I_Patient_Ce ntered_Approach.pdf.

WHO (2015) The End TB Strategy, World Health Origanization. Geneva: World Health Organization. doi: 10.1017/CBO9781107415324.004.

WHO (2017) Tuberculosis Patient Cost 
Surveys: a Handbook. Geneva: World Health Organization.

WHO (2020) Global Tuberculosis Report 2020. Geneva: World Health Organization.

Woodring, S. et al. (2004) 'Development and testing of patient satisfaction measure for inpatient psychiatry care', Journal of Nursing Care Quality, 19(2), pp. 137-148. doi: 10.1097/00001786-200404000-
00011.

$\mathrm{Xu}$, L. et al. (2010) 'Socio-economic factors affecting the success of tuberculosis treatment in six counties of Shandong Province, China.', The International Journal of Tuberculosis and Lung Diseases, 14(4), pp. 440-6. Available at: http://www.ncbi.nlm.nih.gov/pubme d/20202302. 